\title{
Thermic effect of soy versus whey protein - a pilot trial
}

\author{
Bianca Rubin, Joseph Hashim, Sandra Sharp, Jose Antonio* \\ From International Society of Sports Nutrition: 9th Annual ISSN Conference and Expo \\ Clearwater, FL, USA. 22-23 June 2012
}

\section{Background}

Protein has a thermic effect that exceeds both fat or carbohydrate. However, it is unclear if there is a difference in the thermic effect of feeding (TEF) between different protein sources. Thus, the purpose of this study was to determine the thermic effect of an isocaloric feeding of whey versus soy protein.

\section{Methods}

In this single blind cross-over study, young male and female subjects $(n=5$, three males, two females; age range 18-21) consumed 40 grams of either whey (Zero Carb SRO by VPX) or soy protein (Iso-Rich Soy by Jarrow Formulas). Subjects reported to the lab on separate days (with at least 2 days between testing sessions) and underwent 3 hours of resting metabolic rate (RMR) testing. The thermic effect of feeding (TEF) was assessed via oxygen uptake measures at baseline and 1, 2, and 3 hours post-consumption of protein. Data was collected via the ParvoMedics metabolic cart.

\section{Results}

A paired t-test for AUC reveled a 14.54\% greater TEF for the whey protein than soy $(\mathrm{p}<0.05)$. The range amongst the subjects was $4.05 \%-23.36 \%$ greater increase in TEF. The average peak in oxygen uptake was $29.94 \%$ for whey protein and $23.98 \%$ for soy protein, respectively.

\section{Conclusion}

Based on this small sample size, there is evidence to suggest that whey protein may have a greater TEF than soy.

\section{Competing interests}

Jose Antonio is a sports science consultant to VPX Sports.

* Correspondence: exphys@aol.com

Nova Southeastern University, Davie, FL, 33314, USA
Published: 19 November 2012

doi:10.1186/1550-2783-9-S1-P26

Cite this article as: Rubin et al:: Thermic effect of soy versus whey protein - a pilot trial. Journal of the International Society of Sports Nutrition 2012 9(Suppl 1):P26.
Submit your next manuscript to BioMed Central and take full advantage of:

- Convenient online submission

- Thorough peer review

- No space constraints or color figure charges

- Immediate publication on acceptance

- Inclusion in PubMed, CAS, Scopus and Google Scholar

- Research which is freely available for redistribution
() Biomed Central

\section{(Ciomed Central}

(c) 2012 Rubin et al; licensee BioMed Central Ltd. This is an Open Access article distributed under the terms of the Creative Commons Attribution License (http://creativecommons.org/licenses/by/2.0), which permits unrestricted use, distribution, and reproduction in any medium, provided the original work is properly cited. 